\title{
Correction to: Factors associated with suicide attempts among Australian transgender adults
}

Sav Zwickl ${ }^{1}$, Alex Fang Qi Wong ${ }^{1}$, Eden Dowers ${ }^{1}$, Shalem Yiner-Lee Leemaqz ${ }^{1,2}$, Ingrid Bretherton ${ }^{1,3}$, Teddy Cook ${ }^{4}$, Jeffrey D. Zajac ${ }^{1,3}$, Paul S. F. Yip ${ }^{5}$ and Ada S. Cheung ${ }^{1,3^{*}}$

\section{Correction to: BMC Psychiatry 21, 81 (2021)}

https://doi.org/10.1186/s12888-021-03084-7

Following the publication of the original article [1], the authors provided clarifications, additional information, and changes in the text and tables. The changes have been highlighted with bold typeface and are shown in Additional file 1.

The original article [1] has been corrected.

\section{Supplementary Information}

The online version contains supplementary material available at https://doi. org/10.1186/s12888-021-03491-w.

\section{Additional file 1.}

\section{Author details}

${ }^{1}$ Trans Health Research Group, Department of Medicine (Austin Health), The University of Melbourne, Melbourne, Victoria 3084, Australia. ${ }^{2}$ College of Medicine and Public Health, Flinders University, Adelaide, South Australia 5042, Australia. ${ }^{3}$ Department of Endocrinology, Austin Health, 145 Studley Road, Heidelberg, Victoria 3084, Australia. ${ }^{4}$ ACON Health, Surry Hills, New South Wales, Australia. ${ }^{5}$ Centre for Suicide Research and Prevention, The University of Hong Kong, Hong Kong, Hong Kong, China.

Published online: 09 November 2021

\section{Reference \\ 1. Zwickl, et al. Factors associated with suicide attempts among Australian transgender adults. BMC Psychiatry. 2021;21:81. https://doi.org/10.1186/s12 888-021-03084-7.}

The original article can be found online at https://doi.org/10.1186/s12888021-03084-7.

* Correspondence: adac@unimelb.edu.au

${ }^{1}$ Trans Health Research Group, Department of Medicine (Austin Health), The University of Melbourne, Melbourne, Victoria 3084, Australia

${ }^{3}$ Department of Endocrinology, Austin Health, 145 Studley Road, Heidelberg, Victoria 3084, Australia

Full list of author information is available at the end of the article

(C) The Author(s). 2021 Open Access This article is licensed under a Creative Commons Attribution 4.0 International License, which permits use, sharing, adaptation, distribution and reproduction in any medium or format, as long as you give appropriate credit to the original author(s) and the source, provide a link to the Creative Commons licence, and indicate if changes were made. The images or other third party material in this article are included in the article's Creative Commons licence, unless indicated otherwise in a credit line to the material. If material is not included in the article's Creative Commons licence and your intended use is not permitted by statutory regulation or exceeds the permitted use, you will need to obtain permission directly from the copyright holder. To view a copy of this licence, visit http://creativecommons.org/licenses/by/4.0/ The Creative Commons Public Domain Dedication waiver (http://creativecommons.org/publicdomain/zero/1.0/) applies to the data made available in this article, unless otherwise stated in a credit line to the data. 